\title{
Climate-driven changes in the ecological stoichiometry of aquatic ecosystems
}

\author{
Dedmer B van de Waal ${ }^{1,2}$, Antonie M Verschoor ${ }^{2}$, Jolanda MH Verspagen ${ }^{1}$, Ellen van Donk ${ }^{2}$, and Jef Huisman ${ }^{1^{*}}$
}

Advances in ecological stoichiometry, a rapidly expanding research field investigating the elemental composition of organisms and their environment, have shed new light on the impacts of climate change on freshwater and marine ecosystems. Current changes in the Earth's climate alter the availability of carbon and nutrients in lakes and oceans. In particular, atmospheric $\mathrm{CO}_{2}$ concentrations will rise to unprecedented levels by the end of this century, while global warming will enhance stratification of aquatic ecosystems and may thereby diminish the supply of nutrients into the surface layer. These processes enrich phytoplankton with carbon, but suppress nutrient availability. Phytoplankton with a high carbon-to-nutrient content provide poor-quality food for most zooplankton species, which may shift the species composition of zooplankton and higher trophic levels to less nutrient-demanding species. As a consequence, climate-driven changes in plankton stoichiometry may alter the structure and functioning of entire aquatic food webs.

Front Ecol Environ 2010; 8(3): 145-152, doi:10.1890/080178 (published online 25 Jun 2009)

$I^{n}$ 1934, Alfred C Redfield reported that the ratios between the elements carbon, nitrogen, and phosphorus $(\mathrm{C}, \mathrm{N}$, and $\mathrm{P}$, respectively) in marine phytoplankton were remarkably constant (Redfield 1934). His famous $\mathrm{C}: \mathrm{N}: \mathrm{P}$ ratio of $106: 16: 1$ (by atom) has since become known as the "Redfield ratio" (Falkowski and Davis 2004). Redfield further noted that the N:P ratios of phytoplankton resembled the nitrate:phosphate ratio found in the deep waters of the oceans (Redfield 1934). Thus, the elemental composition of marine plankton reflected that of their environment, and vice versa. However, even the seemingly constant pelagic environment is currently affected by changes in the Earth's atmosphere. The 1934 atmosphere contained $\sim 300$ parts per million (ppm) of carbon dioxide $\left(\mathrm{CO}_{2}\right)$, which has risen to the present-day

\section{In a nutshell:}

- Rising levels of atmospheric $\mathrm{CO}_{2}$ enrich aquatic ecosystems with carbon

- Global warming strengthens the vertical stratification of aquatic ecosystems, which suppresses the supply of nutrients from deep water layers into the surface layer

- Enhanced carbon - but reduced nutrient - availability is likely to increase the carbon-to-nutrient content of phytoplankton at a global scale

- Phytoplankton with high carbon-to-nutrient ratios are of low nutritional value for zooplankton

- Such climate-driven changes in plankton stoichiometry may cascade throughout the entire aquatic food web

\footnotetext{
${ }^{1}$ Aquatic Microbiology, Institute for Biodiversity and Ecosystem Dynamics, University of Amsterdam, Amsterdam, Netherlands *(j.huisman@uva.nl); ${ }^{2}$ Department of Aquatic Food Webs, Centre for Limnology, Netherlands Institute of Ecology, Nieuwersluis, Netherlands
}

value of $385 \mathrm{ppm}$, a level that far exceeds that of the natural range of the past 650000 years. Atmospheric $\mathrm{CO}_{2}$ levels are expected to rise further, to $\sim 750 \mathrm{ppm}$ by the year 2100 (Solomon et al. 2007). The rapid increase in atmospheric $\mathrm{CO}_{2}$ and other greenhouse gases is accompanied by global warming. Average global temperatures have risen by $0.6^{\circ} \mathrm{C}$ since 1934 , and an additional $3^{\circ} \mathrm{C}$ increase is expected to occur over the course of the $21 \mathrm{st}$ century (Solomon et al. 2007). These changes in global climate will affect many chemical and physical processes in aquatic ecosystems, with possible implications for the elemental composition of plankton communities.

Ecological stoichiometry is a rapidly expanding research field investigating how the elemental composition of organisms affects ecological processes (Sterner and Elser 2002; Panel 1). Inspired by Redfield and the recent advances in ecological stoichiometry, this review explores the potential impacts of climate change on the $\mathrm{C}$ and nutrient availability in aquatic ecosystems, its consequences for the C:N:P stoichiometry of plankton communities, and its implications for the structure of aquatic food webs.

\section{Rising $\mathrm{CO}_{2}$ and ocean acidification}

The current rise in atmospheric $\mathrm{CO}_{2}$ levels is having a major impact on the $\mathrm{C}$ chemistry of the oceans (Doney et al. 2009). In fact, it is estimated that almost $50 \%$ of the anthropogenic $\mathrm{CO}_{2}$ input into the atmosphere since the advent of the Industrial Revolution has been absorbed by the oceans (Sabine et al. 2004). Compared to the large pool of bicarbonate $\left(\mathrm{HCO}_{3}^{-}\right)$, dissolved $\mathrm{CO}_{2}$ constitutes only a minor fraction of the total concentration of dissolved inorganic carbon (DIC) in the oceans. Yet, rising concentrations of atmospheric $\mathrm{CO}_{2}$ increase the concen- 


\section{Panel 1. Ecological stoichiometry}

The field of ecological stoichiometry (Sterner and Elser 2002) looks at the balance of energy (carbon) and nutrients to describe the complex relationships between organisms and their environment. Using the same mass-balance approach routinely employed in chemistry, ecological stoichiometry provides insight into the feedbacks and constraints operating on $\mathrm{C}$ and nutrient fluxes in food webs. Among autotrophic organisms, including phytoplankton and terrestrial plants, $C$ and nutrients are taken up separately. As a result, $\mathrm{CO}_{2}$ fixation and nutrient acquisition are relatively loosely coupled. This makes autotrophs flexible in their stoichiometry; their C-to-nutrient ratios can vary over large ranges, and partly reflect the resource availability in their environment. For example, when $P$ is available in high concentrations, $C: P$ ratios in phytoplankton cells are often relatively low. Conversely, when $P$ is limiting but light and inorganic $C$ are in ample supply, intracellular $\mathrm{C}: \mathrm{P}$ ratios can become very high (Figure I).

Although the C-to-nutrient stoichiometry of autotrophs may vary widely, many heterotrophic organisms tend to keep their $\mathrm{C}$-to-nutrient ratios within a narrow range (Figure I). This is known as homeostasis. Heterotrophs usually take up $\mathrm{C}$ and nutrients simultaneously, so their $C$ and nutrient uptake reflects the C-to-nutrient ratio supplied by their food. However, the nutrient content in most heterotrophic organisms is relatively high as compared with that in autotrophic organisms (Figure I). Thus, for many herbivores, the nutrient content of their food will be low relative to their own nutrient demands. Yet, different species of heterotrophs may differ in their stoichiometric requirements. For instance, copepods typically have higher C:P ratios than do clado-

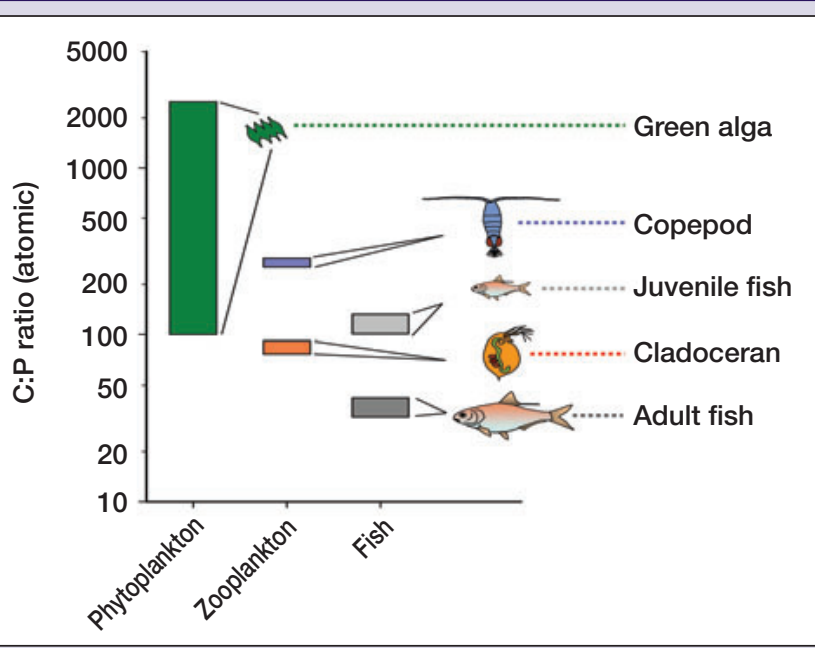

Figure 1. Phytoplankton display a wide range of relatively high C:P ratios, as shown here for the green alga Scenedesmus obliquus (data from Verschoor et al. 2004). Zooplankton and fish have rather narrow stoichiometric ranges (homeostasis). Copepods, such as Eudiaptomus gracilis, typically have higher C:P ratios than do cladocerans, such as Daphnia galeata (data from Vrede et al. 1999). The nutrient stoichiometry may also change during ontogenic development, as illustrated by the C:P ratio of juvenile and adult fish of the gizzard shad (Dorosoma cepedianum; data from Pilati and Vanni 2007). cerans (Sterner and Elser 2002). Furthermore, stoichiometric requirements may vary with the developmental stage of heterotrophs. Larval and juvenile fish, for instance, often have higher C:P ratios than do adult fish (Figure I).

One important implication of the stoichiometric imbalance between autotrophs and their heterotrophic grazers is that grazers can become nutrient-limited. For instance, without stoichiometric considerations, one might think that an increased light supply, which enhances primary production, will benefit heterotrophic grazers, because more food is being produced. However, stoichiometric theory predicts the opposite, because an increased light supply may suppress food quality (Sterner and Elser 2002). Indeed, laboratory and field experiments (Urabe et al. 2002, 2003) have confirmed that greater light availability increased phytoplankton abundance, but also increased the C-to-nutrient content of the phytoplankton, thus decreasing the quality of the zooplankton's food (Figure 5). This change in phytoplankton stoichiometry can suppress the growth of nutrient-demanding zooplankton species (Sterner and Elser 2002; Urabe et al. 2002).

tration of dissolved $\mathrm{CO}_{2}$ in ocean surface waters. Dissolved $\mathrm{CO}_{2}$ reacts with water to form carbonic acid $\left(\mathrm{H}_{2} \mathrm{CO}_{3}\right)$, which rapidly dissociates into $\mathrm{HCO}_{3}{ }^{-}$, releasing a proton and thereby reducing $\mathrm{pH}$ levels. This phenomenon has become known as "ocean acidification" (Caldeira and Wickett 2003; Doney et al. 2009). Since the Industrial Revolution, ocean acidification has decreased the $\mathrm{pH}$ of ocean surface waters by $\sim 0.1$ units, to an average surface $\mathrm{pH}$ of 8.1 (Orr et al. 2005). At atmospheric $\mathrm{CO}_{2}$ levels of $750 \mathrm{ppm}$ - expected by the year 2100 - the $\mathrm{pH}$ of surface seawater will have dropped by an additional 0.3 units, to a $\mathrm{pH}$ of $\sim 7.8$ (Orr et al. 2005). This is equivalent to a doubling of the proton concentration. The projected concentration of dissolved $\mathrm{CO}_{2}$ at that point will be outside the natural range of the past 20 million years (Solomon et al. 2007).

Ocean acidification causes a decrease in the concentration of carbonate ions (Caldeira and Wickett 2003; Solomon et al. 2007). This increases the solubility of cal- cium carbonate $\left(\mathrm{CaCO}_{3}\right)$ in the oceans. Cold waters are less saturated with respect to $\mathrm{CaCO}_{3}$ than are warmer waters; high-latitude ecosystems are therefore likely to be the first to suffer from ocean acidification. Model simulations project that Southern Ocean surface waters will begin to become undersaturated with respect to aragonite, a metastable form of $\mathrm{CaCO}_{3}$, by about the year 2050 (Orr et al. 2005; Doney et al. 2009). By 2100, this undersaturation could extend throughout the entire Southern Ocean and into the sub-Arctic Pacific Ocean. When water becomes undersaturated with aragonite, key marine organisms, such as corals, foraminifers, and coccolithophores, have difficulty in forming their $\mathrm{CaCO}_{3}$ skeletons (Orr et al. 2005; Hoegh-Guldberg et al. 2007). Laboratory experiments with coccolithophores exposed to elevated $\mathrm{CO}_{2}$ yielded malformed and smaller coccoliths (Riebesell et al. 2000), although effects varied depending on the strain and growth conditions (Iglesias-Rodriguez et al. 2008). Many other calcifying organisms, including pteropods and other- 
mollusks, crustaceans, and sea urchins, will also be negatively affected by ocean acidification (Orr et al. 2005; Doney et al. 2009).

\section{Carbon supersaturation in freshwater ecosystems}

In contrast to open ocean waters, many freshwater ecosystems, estuaries, and some coastal environments receive substantial amounts of $\mathrm{C}$ from terrestrial ecosystems (Sobek et al. 2005). This occurs mainly in the form of dissolved organic carbon (DOC). Bacterial activity mineralizes the available DOC into $\mathrm{CO}_{2}$. As a result, the $\mathrm{CO}_{2}$ concentration of lakes is usually not in equilibrium with the atmosphere, but is related to the concentration of DOC (Figure 2). In fact, $\mathrm{CO}_{2}$ concentrations of 1000-3000 ppm are quite common in lakes. On a global basis, inland waters receive up to 1.9 petagrams $(\mathrm{Pg}) \mathrm{C}$ year $^{-1}$ (equal to $1.9 \times 10^{15} \mathrm{~g} \mathrm{C}$ year $^{-1}$ ) from the surrounding watershed, of which about half is ultimately flushed into the oceans (Cole et al. 2007). A fraction of the $\mathrm{C}$ received by inland waters is buried in sediments, whereas an estimated 0.8 $\mathrm{Pg} \mathrm{C}_{\text {year }}{ }^{-1}$ is processed by aquatic biota, where it is finally respired to $\mathrm{CO}_{2}$ (Cole et al. 2007; although the exact values are still under debate; LJ Tranvik pers comm). Accordingly, most inland waters are supersaturated with $\mathrm{CO}_{2}$, and thus serve as net sources of $\mathrm{CO}_{2}$ to the atmosphere (Sobek et al. 2005; Cole et al. 2007).

Global warming and rising atmospheric $\mathrm{CO}_{2}$ levels may alter the input of DOC into freshwater ecosystems, although the magnitude and direction of these changes will vary regionally. At high latitudes, rising temperatures will thaw large areas covered by permafrost in Siberia, Canada, and Alaska, releasing massive amounts of trapped organic $\mathrm{C}$ that may flow into ponds and lakes (Zimov et al. 2006). Climate scenarios also predict more extreme rainfall events and more frequent storms in many parts of the world (Solomon et al. 2007), which may result in increased runoff of DOC from terrestrial ecosystems into lakes (Hinton et al. 1997). Conversely, DOC concentrations in the Experimental Lakes Area in Canada decreased by $15-25 \%$ during two decades of climatic warming, as a result of reduced streamflow caused by drought (Schindler et al. 1997). Rising atmospheric $\mathrm{CO}_{2}$ concentrations lead to increased stomatal closure of terrestrial vegetation. This reduces plant transpiration, and has been estimated to increase global runoff by $6 \%$ (Betts et al. 2007). In peatlands, elevated $\mathrm{CO}_{2}$ induces shifts in plant species composition, which could amplify DOC export from peatland catchments (Fenner et al. 2007). Other processes also affect the DOC input into freshwater ecosystems, however. For instance, increased DOC concentrations in lakes in
Europe and North America have been explained by a reduction in atmospheric acid deposition (Monteith et al. 2007). All in all, the effects of climate change on DOC concentrations in lakes will greatly depend on the local setting (eg local meteorology, catchment hydrology, land use, vegetation, and water retention times). Yet, the processes described above suggest that DOC concentrations may increase in many lakes.

\section{Global warming and stratification}

Rising temperatures influence the physical structure of aquatic ecosystems. In particular, warming of the upper layers of lakes and oceans enhances the density difference between the surface mixed layer and the deeper waters beneath. All else being equal, this increased density difference will strengthen the vertical stratification of both lakes (Jöhnk et al. 2008; Peeters et al. 2008) and oceans (Sarmiento et al. 2004; Doney 2006). Stratification suppresses vertical mixing across the density gradient, with contrasting effects on nutrient and light availability for phytoplankton growth. On the one hand, stratification reduces the nutrient influx from deep, nutrient-rich waters into the surface mixed layer, thus limiting the availability of nutrients for phytoplankton growth (Behrenfeld et al. 2006; Huisman et al. 2006). On the other hand, stratification entrains phytoplankton populations in the surface mixed layer, thereby improving light conditions for phytoplankton growth (Huisman et al. 1999; Berger et al. 2007).

Many waters in the tropics and subtropics are perma- 


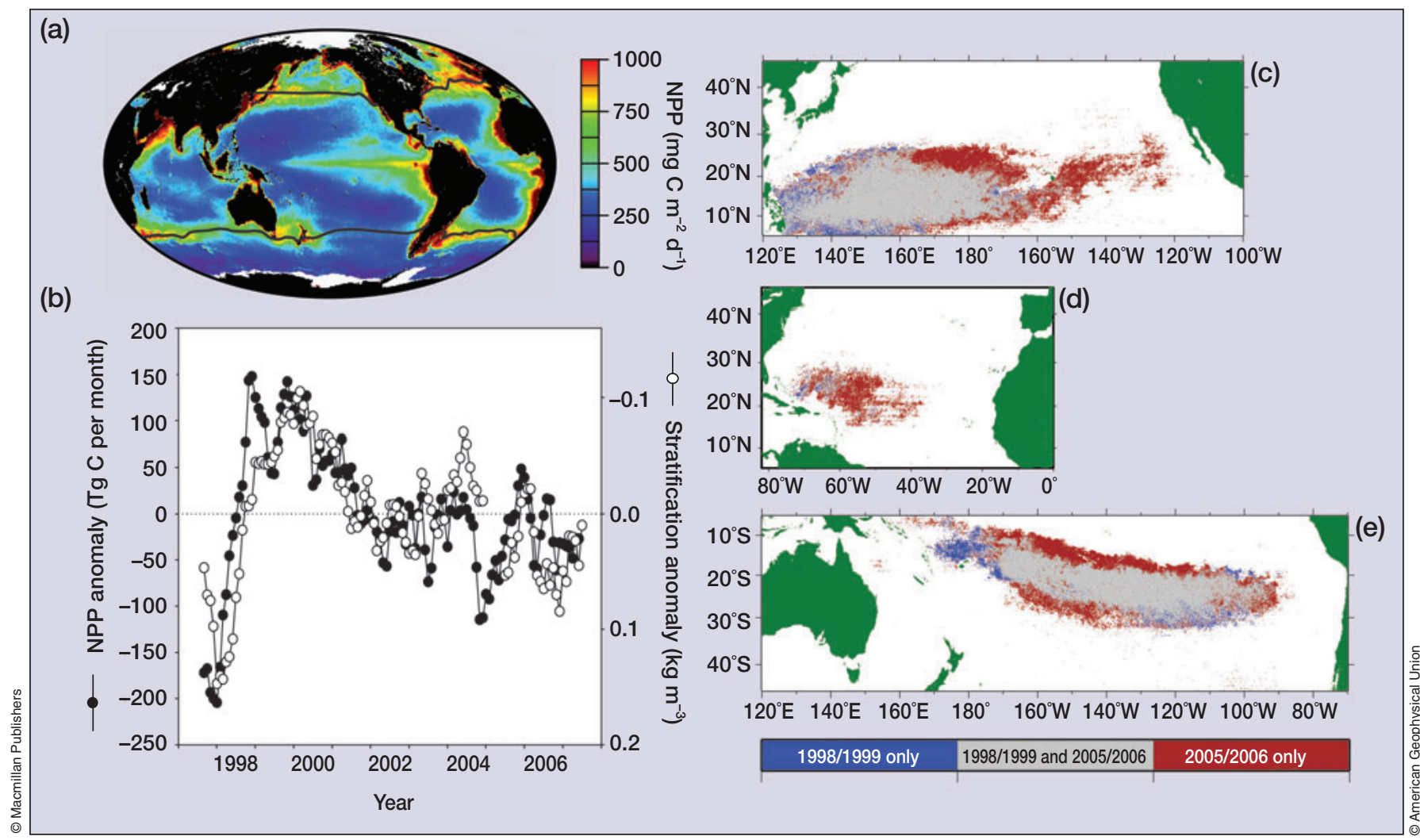

Figure 3. Relationships between stratification and primary production. (a) Global distribution of annual net primary production (NPP), with low values (blue) in permanently stratified waters of subtropical and tropical oceans. (b) Changes in ocean stratification (open circles) are well correlated with NPP anomalies (closed circles) in the subtropical and tropical oceans (Pearson product-moment correlation: $\left.\mathrm{r}^{2}=0.73 ; \mathrm{n}=112 ; \mathrm{P}<0.001\right)$. Expansion of waters with very low net primary production during the past decade, for (c) North Pacific Ocean, (d) North Atlantic Ocean, and (e) South Pacific Ocean. Gray areas had very low chlorophyll concentrations in both 1998/1999 and 2005/2006, blue areas only in 1998/1999, and red areas only in 2005/2006. ([a] and [b] from Behrenfeld et al. 2006; adapted with permission from Macmillan Publishers Ltd: Nature. [c-e] from Polovina et al. 2008; reproduced with permission from the American Geophysical Union.)

nently stratified. Nutrient concentrations in the surface mixed layer of these waters are strongly depleted (Karl et al. 1997; Huisman et al. 2006). As a result of severe nutrient limitation, permanently stratified oceans in the tropics and subtropics are characterized by extremely low primary production (Figure 3a, b). Climate-ocean models predict that, by the year 2050, the ocean area experiencing permanent stratification will have expanded by $4.0 \%$ and $9.4 \%$ in the Northern and Southern Hemispheres, respectively (Sarmiento et al. 2004), thereby reducing overall ocean productivity (Behrenfeld et al. 2006). These predictions are surpassed by recent observations, which indicate a much faster expansion of the ocean's least productive waters over the past 9 years (Figure 3c-e; Polovina et al. 2008).

In the temperate zone and at high latitudes, waters are not permanently stratified, and deep mixing during winter and/or spring transfers nutrients into the surface layer. In these regions, phytoplankton growth is often light-limited in winter, due to short day lengths as well as deep vertical mixing. Climate warming causes an earlier onset of stratification in spring, which brings the phytoplankton cells into the well-lit surface layer while nutrients are not yet depleted, and thereby favors their growth. This leads to an earlier spring bloom and a substantially longer growing season in the temperate zone (Winder and Schindler 2004; Peeters et al. 2008).

\section{Changes in phytoplankton stoichiometry}

The elemental composition of phytoplankton can vary widely, and often reflects the resource availability in their environment (Sterner and Elser 2002). Climate-driven changes in C, light, and nutrient availability are therefore likely to affect phytoplankton stoichiometry. In dense phytoplankton blooms, the photosynthetic demand for inorganic $\mathrm{C}$ can be very high, and this can deplete inorganic $\mathrm{C}$ to limiting concentrations (Ibelings and Maberly 1998). Rising $\mathrm{CO}_{2}$ levels may alleviate these dense blooms from C limitation, especially in low-alkalinity freshwater ecosystems. In marine ecosystems, however, $\mathrm{DIC}$ is dominated by vast amounts of $\mathrm{HCO}_{3}^{-}$. Many phytoplankton species can take up both dissolved $\mathrm{CO}_{2}$ and $\mathrm{HCO}_{3}^{-}$(Kaplan and Reinhold 1999; Martin and Tortell 2008). Inorganic $\mathrm{C}$ is therefore rarely a limiting resource in marine ecosystems. However, large, species-specific 
differences exist in the relative uptake rates of $\mathrm{HCO}_{3}{ }^{-}$ versus $\mathrm{CO}_{2}$ (Martin and Tortell 2008). This interspecific variability will likely have important implications for the phytoplankton species composition in response to rising $\mathrm{CO}_{2}$ concentrations.

In a recent, large-scale mesocosm experiment in a Norwegian fjord, an increase of the $\mathrm{CO}_{2}$ concentration to $1050 \mathrm{ppm}$ resulted in 39\% more uptake of inorganic C by the natural plankton community (Bellerby et al. 2007; Riebesell et al. 2007). Since nutrient uptake remained largely unaffected in this experiment, this resulted in enhanced uptake of $\mathrm{C}$ relative to that of $\mathrm{N}$ and $\mathrm{P}$ (Figure 4). Furthermore, recent laboratory experiments have shown that increased concentrations of $\mathrm{CO}_{2}$ stimulated both $\mathrm{N}$ and $\mathrm{C}$ fixation in a marine $\mathrm{N}$-fixing cyanobacterium (Hutchins et al. 2007; Levitan et al. 2007). For these N-fixing organisms, C:N ratios did not change with increasing $\mathrm{CO}_{2}$ availability, because their cellular $\mathrm{N}$ and $\mathrm{C}$ contents increased in parallel. However, P uptake was not stimulated, so that their C:P and N:P ratios increased markedly at higher $\mathrm{CO}_{2}$ levels (Hutchins et al. 2007; Levitan et al. 2007).

Changes in stratification patterns are likely to affect phytoplankton stoichiometry in two ways. A stronger stratification (1) reduces the nutrient supply from deep waters below and (2) keeps the phytoplankton in the well-lit surface layer. Phytoplankton exposed to these nutrient-limited but light-saturated conditions typically show increased cellular C-to-nutrient ratios (Sterner and Elser 2002). Moreover, a reduced $\mathrm{N}$ supply and increased light availability promote the competitive success of $\mathrm{N}$-fixing cyanobacteria (Agawin et al. 2007). The proliferation of these organisms may force $\mathrm{P}$ concentrations in surface waters to limiting values. This mechanism seems to apply to the subtropical Pacific Ocean, where the presence of $\mathrm{N}$ fixing organisms yields an overall increase in cellular N:P ratios, and shifts the entire ecosystem toward $\mathrm{P}$ limitation (Karl et al. 1997). This suggests that, with climate-driven warming and the expansion of ocean stratification, cellular C-to-nutrient ratios - and in particular C:P ratios - are likely to increase in substantial parts of the world's oceans.

Thus, both rising atmospheric $\mathrm{CO}_{2}$ levels and enhanced stratification by global warming may shift phytoplankton stoichiometry in a similar direction, causing an increased C-to-nutrient ratio of the phytoplankton community and associated changes in phytoplankton species composition toward species that can proliferate under high $\mathrm{CO}_{2} /$ low nutrient conditions.

\section{Implications for zooplankton and higher trophic levels}

The elemental composition of phytoplankton communities affects the cellular concentrations of proteins, fatty acids, and various other phytoplankton constituents important for zooplankton growth (Sterner and Elser 2002; Jensen and Verschoor 2004). The C-to-nutrient ratio of phytoplankton is therefore a major determinant of

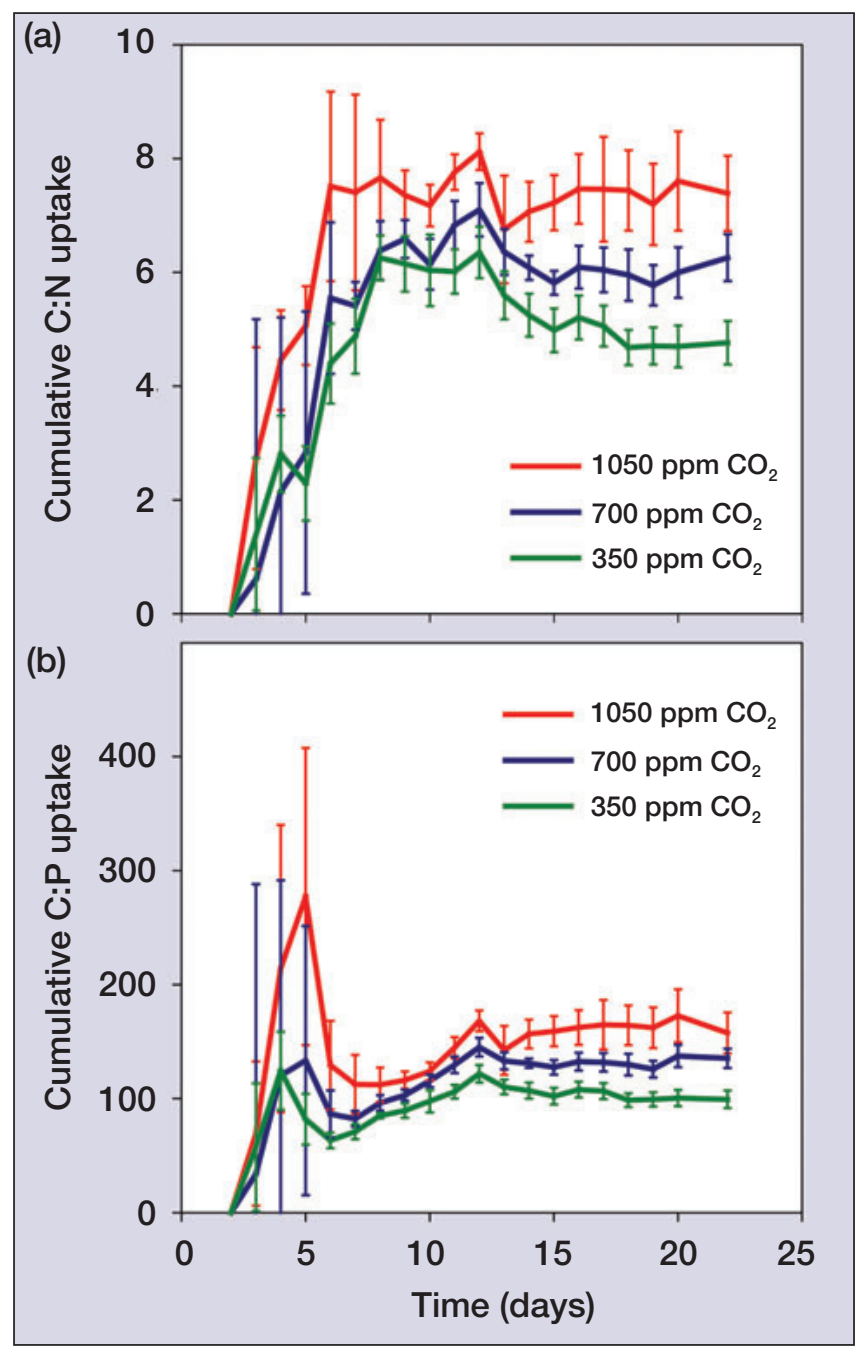

Figure 4. Carbon-to-nutrient uptake ratios during a marine $\mathrm{CO}_{2}$ enrichment study. The graphs illustrate (a) C uptake relative to $N$ uptake (C:N), and (b) $C$ uptake relative to $P$ uptake $(\mathrm{C}: \mathrm{P})$, both integrated over the duration of the experiment from day 2 onwards. The treatments consisted of 350, 700, and 1050 ppm $\mathrm{CO}_{2}$, represented by green, blue, and red lines, respectively. Error bars indicate one standard deviation. (From Bellerby et al. 2007.)

their quality as food for zooplankton (Panel 1). Zooplankton can become nutrient limited if the nutrient content of their food is low as compared with their nutrient demands. Several zooplankton species are capable of compensating for the reduced nutrient content of their food through compensatory feeding (ie by increasing their feeding rates). Nevertheless, the costs of compensatory feeding and processing of surplus $\mathrm{C}$ restrict this strategy to a limited range of C-to-nutrient ratios. Indeed, laboratory experiments have shown that growth rates of herbivorous zooplankton species, such as the cladoceran Daphnia and the rotifer Brachionus, are reduced when feeding on phytoplankton with high C:P ratios (Sterner and Elser 2002; Urabe et al. 2003; Jensen and Verschoor 2004).

As an example, laboratory experiments performed by Urabe et al. (2003) showed that elevation of the $\mathrm{CO}_{2}$ 


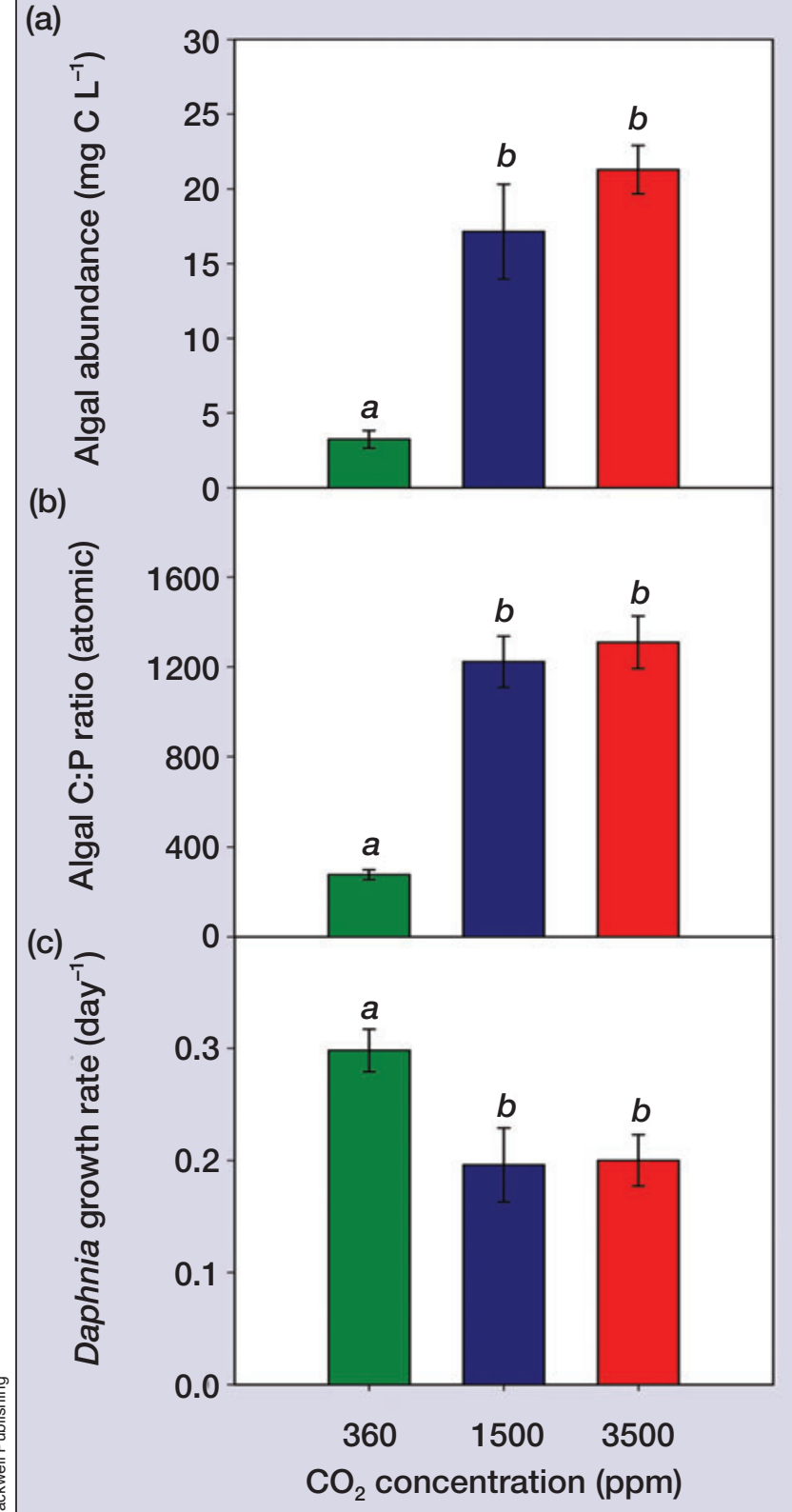

Figure 5. Effects of $\mathrm{CO}_{2}$ enrichment in a laboratory experiment. (a) Biomass of the green alga Scenedesmus, (b) the corresponding algal C:P stoichiometry, and (c) specific growth rates of Daphnia when fed with these green algae. The treatments consisted of 360, 1500, and $3500 \mathrm{ppm} \mathrm{CO}_{2}$, represented by green, blue, and red bars, respectively. Error bars indicate the standard error of the mean. Bars with different letters were significantly different $(\mathrm{P}<0.05$, Tukey's pairwise comparison). (From Urabe et al. 2003; adapted with permission from Blackwell Publishing Ltd: Global Change Biology.)

concentration from 360 to $1500 \mathrm{ppm}$ resulted not only in an increased phytoplankton biomass (Figure 5a), but also in an increased C:P ratio (Figure $5 b$ ). This reduction in food quality suppressed the growth rate of the cladoceran Daphnia at elevated $\mathrm{CO}_{2}$ (Figure 5c). Similar results were obtained by Urabe and Waki (2009), although the latter study also shows that this adverse effect of rising $\mathrm{CO}_{2}$ on
Daphnia growth can be mitigated by mixed algal diets. Other zooplankton species with lower P requirements, like copepods, may be able to sustain their growth when feeding on phytoplankton with high C:P ratios (Panel 1). Accordingly, if growth rates of high P-demanding species, such as cladocerans, are reduced, low P-demanding species, such as copepods, might gain a competitive advantage. This may cause shifts in zooplankton species composition in response to climate-driven changes in phytoplankton stoichiometry.

An elemental imbalance between phytoplankton and zooplankton may also affect the recycling efficiency of different elements (Sterner and Elser 2002). For instance, zooplankton feeding on phytoplankton with a high $\mathrm{N}: \mathrm{P}$ ratio show an increased release of $\mathrm{N}$ as compared with that of P (Elser and Urabe 1999). Similar relationships apply for C-to-nutrient ratios, as zooplankton excrete the excess C obtained in their food (Hessen and Anderson 2008). Consequently, a climate-driven increase in phytoplankton C-to-nutrient ratios may enhance $\mathrm{C}$ release by zooplankton, whereas nutrients are retained. This positive feedback will further increase DOC concentrations and, subsequently, the $\mathrm{CO}_{2}$ availability for phytoplankton. Since nutrient limitation continues or is enhanced, because of reduced nutrient recycling by herbivores, this leads to even higher $\mathrm{C}$-to-nutrient ratios in the phytoplankton.

The potential increase in C-to-nutrient ratios of phytoplankton and the subsequent shift in zooplankton species composition may cascade up through higher trophic levels. During the past decades, shifts in large zooplankton and fish communities have been observed in many seas and oceans. For instance, recent studies indicate that krill in the Southern Ocean are gradually being replaced by salp species (Atkinson et al. 2004), and jellyfish numbers seem to be on the rise worldwide (Purcell 2005). Furthermore, fish size distributions are shifting toward smaller fish in various marine ecosystems (Pauly et al. 2005). Although these changes are primarily attributed to fisheries, climate change may also be playing a role (Pauly et al. 2005; Purcell 2005). Interestingly, salp seems to have a low body $\mathrm{P}$ demand as compared with that of copepods and krill, whereas jellyfish and small fish have a lower body $\mathrm{P}$ demand than larger fish (Ikeda and Mitchell 1982; Malej et al. 1993; Sterner and Elser 2002). Furthermore, there are indications that the growth rates of some P-rich fish species, particularly of herbivorous fish growing on high C:P food, can become P limited (Hood et al. 2005). A climate-driven decrease in the $\mathrm{P}$ content of plankton may therefore exacerbate the impacts that fisheries have on the species composition of higher trophic levels in marine pelagic food webs.

\section{Caveats and conclusions}

Climate change can have many impacts on aquatic ecosystems. It may favor the development of harmful algal blooms (Paerl and Huisman 2008), cause ocean 
acidification (Caldeira and Wickett 2003), and affect the biogeographical distribution of many species (Hays et al. 2005). Current knowledge about the impacts of climate change on plankton stoichiometry is still limited. Although we have argued that climate change is likely to increase the C-to-nutrient stoichiometry of plankton communities, several processes may impede or completely reverse this pattern. For instance, as a result of global warming, air temperatures are increasing to a greater extent than ocean water temperatures, causing more frequent storms (Solomon et al. 2007). Storms can prevent or suppress stratification, and the resultant vertical mixing of the water column may enhance the flux of nutrients from deeper waters into surface layers. Furthermore, stoichiometric effects of climate change may be mitigated or even counteracted by eutrophication, through anthropogenic $\mathrm{N}$ and $\mathrm{P}$ loading. These processes provide more nutrients for phytoplankton growth, especially near the more densely human populated regions of our planet, and may thereby lead to local or regional trends in plankton stoichiometry that deviate from our expected pattern.

Moreover, the response of species, communities, and ecosystems to changing environmental conditions can be highly complex, with many non-linear interactions and surprising feedbacks (Scheffer et al. 2001; Benincà et al. 2008). Many planktonic organisms are also quite flexible in their stoichiometry, and have considerable potential for physiological acclimation and evolutionary adaptation to changing $\mathrm{C}$ and nutrient conditions (Sterner and Elser 2002). It may therefore be difficult to predict longterm changes in the ecological stoichiometry of aquatic ecosystems, based on only a few climatic drivers.

Nevertheless, by and large, the current state of knowledge indicates that rising atmospheric $\mathrm{CO}_{2}$ levels will increase $\mathrm{CO}_{2}$ availability for biological production, while global warming will tend to strengthen vertical stratification of aquatic ecosystems, thus reducing nutrient availability in the surface mixed layer. It seems plausible that the combination of rising $\mathrm{CO}_{2}$ availability and reduced nutrient levels will result in higher phytoplankton C-tonutrient ratios. These alterations in phytoplankton stoichiometry are likely to suppress zooplankton growth, shift zooplankton species composition to less nutrientdemanding species, and thereby affect the entire aquatic food web. If we were to follow in the footsteps of Redfield (1934) and measure plankton stoichiometry at the end of the 21st century, we might discover a different Redfield ratio, one reflecting a C-rich world.

\section{Acknowledgements}

This review was inspired by a scientific symposium supported by the Royal Netherlands Academy of Arts and Sciences (KNAW). We thank MJ Behrenfeld, RGJ Bellerby, JJ Polovina, S Sobek, and J Urabe for kind provision of data and figures, and DO Hessen, RW Sterner, and J Urabe for helpful comments on the manuscript.
The research of DBvdW, AMV, and JMHV was supported by the Earth and Life Sciences Foundation (ALW), which is subsidized by the Netherlands Organization for Scientific Research (NWO). This is publication 4517 of the Netherlands Institute of Ecology (NIOO-KNAW).

\section{References}

Agawin NSR, Rabouille S, Veldhuis MJW, et al. 2007. Competition and facilitation between unicellular nitrogen-fixing cyanobacteria and non-nitrogen-fixing phytoplankton species. Limnol Oceanogr 52: 2233-48.

Atkinson A, Siegel V, Pakhomov E, and Rothery P. 2004. Longterm decline in krill stock and increase in salps within the Southern Ocean. Nature 432: 100-03.

Behrenfeld MJ, O'Malley RT, Siegel DA, et al. 2006. Climate-driven trends in contemporary ocean productivity. Nature 444: $752-55$.

Bellerby RGJ, Schulz KG, Riebesell U, et al. 2007. Marine ecosystem community carbon and nutrient uptake stoichiometry under varying ocean acidification during the PeECE III experiment. Biogeosciences Discuss 4: 4631-52.

Benincà E, Huisman J, Heerkloss R, et al. 2008. Chaos in a longterm experiment with a plankton community. Nature 451: $822-25$.

Berger SA, Diehl S, Stibor H, et al. 2007. Water temperature and mixing depth affect timing and magnitude of events during spring succession of the plankton. Oecologia 150: 643-54.

Betts RA, Boucher O, Collins M, et al. 2007. Projected increase in continental runoff due to plant responses to increasing carbon dioxide. Nature 448: 1037-41.

Caldeira $\mathrm{K}$ and Wickett ME. 2003. Anthropogenic carbon and ocean pH. Nature 425: 365.

Cole JJ, Prairie YT, Caraco NF, et al. 2007. Plumbing the global carbon cycle: integrating inland waters into the terrestrial carbon budget. Ecosystems 10: 171-84.

Doney SC. 2006. Plankton in a warmer world. Nature 444: 695-96.

Doney SC, Fabry VJ, Feely RA, and Kleypas JA. 2009. Ocean acidification: the other $\mathrm{CO}_{2}$ problem. Annu Rev Mar Sci 1: 169-92.

Elser JJ and Urabe J. 1999. The stoichiometry of consumer-driven nutrient recycling: theory, observations, and consequences. Ecology 80: 735-51.

Falkowski PG and Davis CS. 2004. Natural proportions. Nature 431: 131 .

Fenner N, Ostle N, McNamara N, et al. 2007. Elevated $\mathrm{CO}_{2}$ effects on peatland plant community carbon dynamics and DOC production. Ecosystems 10: 635-47.

Hays GC, Richardson AJ, and Robinson C. 2005. Climate change and marine plankton. Trends Ecol Evol 20: 337-44.

Hessen DO and Anderson TR. 2008. Excess carbon in aquatic organisms and ecosystems: physiological, ecological, and evolutionary implications. Limnol Oceanogr 53: 1685-96.

Hinton MJ, Schiff SL, and English MC. 1997. The significance of storms for the concentration and export of dissolved organic carbon from two Precambrian Shield catchments. Biogeochemistry 36: 67-88.

Hoegh-Guldberg O, Mumby PJ, Hooten AJ, et al. 2007. Coral reefs under rapid climate change and ocean acidification. Science 318: $1737-42$.

Hood JM, Vanni MJ, and Flecker AS. 2005. Nutrient recycling by two phosphorus-rich grazing catfish: the potential for phosphorus-limitation of fish growth. Oecologia 146: 247-57.

Huisman J, van Oostveen P, and Weissing FJ. 1999. Critical depth and critical turbulence: two different mechanisms for the development of phytoplankton blooms. Limnol Oceanogr 44: 1781-87.

Huisman J, Pham Thi NN, Karl DM, and Sommeijer B. 2006. 
Reduced mixing generates oscillations and chaos in the oceanic deep chlorophyll maximum. Nature 439: 322-25.

Hutchins DA, Fu F-X, Zhang Y, et al. 2007. $\mathrm{CO}_{2}$ control of Trichodesmium $\mathrm{N}_{2}$ fixation, photosynthesis, growth rates, and elemental ratios: implications for past, present, and future ocean biogeochemistry. Limnol Oceanogr 52: 1293-1304.

Ibelings BW and Maberly SC. 1998. Photoinhibition and the availability of inorganic carbon restrict photosynthesis by surface blooms of cyanobacteria. Limnol Oceanogr 43: 408-19.

Iglesias-Rodriguez MD, Halloran PR, Rickaby REM, et al. 2008. Phytoplankton calcification in a high- $\mathrm{CO}_{2}$ world. Science 320: 336-40.

Ikeda T and Mitchell AW. 1982. Oxygen uptake, ammonia excretion and phosphate excretion by krill and other Antarctic zooplankton in relation to their body size and chemical composition. Mar Biol 71: 283-98.

Jensen TC and Verschoor AM. 2004. Effects of food quality on life history of the rotifer Brachionus calyciflorus Pallas. Freshwater Biol 49: 1138-51.

Jöhnk KD, Huisman J, Sharples J, et al. 2008. Summer heatwaves promote blooms of harmful cyanobacteria. Glob Change Biol 14: 495-512.

Kaplan A and Reinhold L. 1999. $\mathrm{CO}_{2}$ concentrating mechanisms in photosynthetic microorganisms. Annu Rev Plant Phys 50: 539-70.

Karl DM, Letelier R, Tupas L, et al. 1997. The role of nitrogen fixation in biogeochemical cycling in the subtropical North Pacific Ocean. Nature 388: 533-38.

Levitan O, Rosenberg G, Setlik I, et al. 2007. Elevated $\mathrm{CO}_{2}$ enhances nitrogen fixation and growth in the marine cyanobacterium Trichodesmium. Glob Change Biol 13: 531-38.

Malej A, Faganeli J, and Pezdiã J. 1993. Stable isotope and biochemical fractionation in the marine pelagic food chain: the jellyfish Pelagia noctiluca and net zooplankton. Mar Biol 116: 565-70.

Martin CL and Tortell PD. 2008. Bicarbonate transport and extracellular carbonic anhydrase in marine diatoms. Physiol Plantarum 133: 106-16.

Monteith DT, Stoddard JL, Evans CD, et al. 2007. Dissolved organic carbon trends resulting from changes in atmospheric deposition chemistry. Nature 450: 537-40.

Orr JC, Fabry VJ, Aumont O, et al. 2005. Anthropogenic ocean acidification over the twenty-first century and its impact on calcifying organisms. Nature 437: 681-86.

Paerl HW and Huisman J. 2008. Blooms like it hot. Science 320 $57-58$.

Pauly D, Watson R, and Alder J. 2005. Global trends in world fisheries: impacts on marine ecosystems and food security. Philos $T$ $R$ Soc B 360: 5-12.

Peeters F, Straile D, Lorke A, and Livingstone DM. 2008. Earlier onset of the spring phytoplankton bloom in lakes of the temperate zone in a warmer climate. Glob Change Biol 13: 1898-1909.

Pilati A and Vanni MJ. 2007. Ontogeny, diet shifts, and nutrient stoichiometry in fish. Oikos 116: 1663-74.
Polovina JJ, Howell EA, and Abecassis M. 2008. Ocean's least productive waters are expanding. Geophys Res Lett 35: L03618. doi:10.1029/2007GL031745.

Purcell JE. 2005. Climate effects on formation of jellyfish and ctenophore blooms: a review. J Mar Biol Assoc UK 85: 461-76.

Redfield AC. 1934. On the proportions of organic derivatives in sea water and their relation to the composition of plankton. In: Daniel RJ (Ed). James Johnstone memorial volume. Liverpool, UK: Liverpool University Press.

Riebesell U, Zondervan I, Rost B, et al. 2000. Reduced calcification of marine plankton in response to increased atmospheric $\mathrm{CO}_{2}$. Nature 407: 364-67.

Riebesell U, Schulz KG, Bellerby RGJ, et al. 2007. Enhanced biological carbon consumption in a high $\mathrm{CO}_{2}$ ocean. Nature 450 : 545-49.

Sabine CL, Feely RA, Gruber N, et al. 2004. The oceanic sink for anthropogenic $\mathrm{CO}_{2}$. Science 305: 367-71.

Sarmiento JL, Slater R, Barber R, et al. 2004. Response of ocean ecosystems to climate warming. Global Biogeochem Cy 8: GB3003. doi:10.1029/2003GB002134.

Scheffer M, Carpenter S, Foley JA, et al. 2001. Catastrophic shifts in ecosystems. Nature 413: 591-96.

Schindler DW, Curtis PJ, Bayley SE, et al. 1997. Climate-induced changes in the dissolved organic carbon budgets of boreal lakes. Biogeochemistry 36: 9-28.

Sobek S, Tranvik L, and Cole JJ. 2005. Temperature independence of carbon dioxide supersaturation in global lakes. Global Biogeochem Cy 19: GB2003. doi:10.1029/2004GB002264.

Solomon S, Qin D, Manning M, et al. 2007. Climate change 2007: the physical science basis. Contribution of Working Group I to the Fourth Assessment Report of the Intergovernmental Panel on Climate Change. Cambridge, UK: Cambridge University Press.

Sterner RW and Elser JJ. 2002. Ecological stoichiometry. The biology of elements from molecules to the biosphere. Princeton, NJ: Princeton University Press.

Urabe J, Kyle M, Makino W, et al. 2002. Reduced light increases herbivore production due to stoichiometric effects of light/nutrient balance. Ecology 83: 619-27.

Urabe J, Togari J, and Elser JJ. 2003. Stoichiometric impacts of increased carbon dioxide on a planktonic herbivore. Glob Change Biol 9: 818-25.

Urabe J and Waki N. 2009. Mitigation of adverse effects of rising $\mathrm{CO}_{2}$ on a planktonic herbivore by mixed algal diets. Glob Change Biol 15: 523-31.

Verschoor AM, Vos M, and Van der Stap I. 2004. Inducible defences prevent strong population fluctuations in bi- and tritrophic food chains. Ecol Lett 7: 1143-48.

Vrede T, Andersen T, and Hessen DO. 1999. Phosphorus distribution in three crustacean zooplankton species. Limnol Oceanogr 44: 225-29.

Winder M and Schindler DE. 2004. Climatic effects on the phenology of lake processes. Glob Change Biol 10: 1844-56.

Zimov SA, Schuur EAG, and Chapin III FS. 2006. Permafrost and the global carbon budget. Science 312: 1612-13. 